\title{
SUPERCRITICAL FLUID EXTRACTION OF MOLYBDENUM COMPLEXES AND ITS ISOTOPES WITH CARBON DIOXIDE
}

\author{
B. V.Borts ${ }^{1}$, L.A.Bulavin ${ }^{2}$, S.F.Skoromnaya ${ }^{1}$, V.I. Tkachenko ${ }^{1,3} *$ \\ ${ }^{1}$ National Science Center "Kharkiv Institute of Physics and Technology", 61108 Kharkiv, Ukraine; \\ ${ }^{2}$ Taras Shevchenko National University, 01601 Kyiv, Ukraine; \\ ${ }^{3}$ V.N. Karazin Kharkiv National University, 61022 Kharkiv, Ukraine
}

(Received August 27, 2019)

\begin{abstract}
Separation of molybdenum complexes and its isotopes by supercritical fluid extraction (SFE) with carbon dioxide was experimentally investigated. The type of modifier, which provides increasing the efficiency of the metal and its isotopes separation, was determined. Extraction of molybdenum isotope complexes was carried out in the updated SFE-U unit at a constant value of the initial pressure $\mathrm{P}=20 \mathrm{MPa}$ and constant temperatures of the upper $\left(\mathrm{T}_{1}=\right.$ $\left.35{ }^{\circ} \mathrm{C}\right)$ and bottom $\left(\mathrm{T}_{2}=45{ }^{\circ} \mathrm{C}\right)$ flanges of the extraction chamber. The exposure time of the extract and the level along the extraction chamber height, from which the eluent was sampled, were set in the experiments. It is shown, that at a certain sampling height and at certain exposure times, change in the natural content of Mo isotopes in the extracts takes place.
\end{abstract}

PACS: 03.65.Pm, 03.65.Ge, 61.80.Mk

\section{INTRODUCTION}

As it is known, natural molybdenum consists of a mixture of 7 stable isotopes [1, 2]: ${ }^{92} \mathrm{Mo}$ (occurence $14.84 \%)$, ${ }^{94} \mathrm{Mo}(9.25 \%),{ }^{95} \mathrm{Mo}$ (15.92\%), ${ }^{96} \mathrm{Mo}(16,68 \%),{ }^{97} \mathrm{Mo}(9.55 \%),{ }^{98} \mathrm{Mo}(24.13 \%)$, and ${ }^{100} \mathrm{Mo}(9.63 \%)$.

The most significant place in the list of isotopes takes ${ }^{99} \mathrm{Mo}$ and its application in medical practice is well studied [3]. It is the mother nucleus of ${ }^{99 m} \mathrm{Tc}$ $\left(\mathrm{T}_{1 / 2}=66 \mathrm{~h}\right.$, emits $\beta$-particles and $\gamma$-rays $)$. The decay scheme of ${ }^{99}$ Mo has the form [3]:

$$
\begin{array}{r}
\quad{ }_{42}^{99} \mathrm{Mo}\left(T_{1 / 2}=66 h\right) \rightarrow{ }_{43}^{99 m} \mathrm{Tc}\left(T_{1 / 2}=6 h\right) \rightarrow \\
\rightarrow{ }_{43}^{99} \mathrm{Tc}\left(T_{1 / 2}=2 \cdot 10^{5} \text { years }\right)+\gamma(0.1495 \mathrm{MeV}),
\end{array}
$$

where $\gamma$ - quanta with energy of $0.1405 \mathrm{MeV}$ are emitted as a result of ${ }^{99 m} \mathrm{Tc}$ decay.

${ }^{99 m}$ Tc isotope in the form of various pharmaceuticals is used in medical diagnostics for visualization of thyroid and salivary glands, heart and large vessels, skeleton, brain tumors, urinary organs, etc.

${ }^{99 m}$ Tc isotope generated as a result of the decay (1) has a sufficiently long lifetime $-2 \cdot 10^{5}$ years and is rapidly removed from the body [3].

Start of production and organizing the application of ${ }^{99 m}$ Tc isotope in Ukraine are relevant objectives due to the large number of cancers compared to world standards. According to the Bulletin of the National Cancer Registry of Ukraine, 135714 cancers were detected in 2016 without taking into account Lugansk and Donetsk regions, the Autjonomous Republic of
Crimea and Sevastopol. 52.4\% of the detected cases were attributed to the I and II stages, which have a high degree of medication-based treatment.

Therefore, ${ }^{99 m} \mathrm{Tc}$ isotope is an extremely necessary means for detecting cancer at an early stage.

Production of mother ${ }^{99 m}$ Mo isotope can be realized as a result of [4]:

- reaction of ${ }^{235} \mathrm{U}$ nuclear fission in ${ }^{235} \mathrm{U}(\mathrm{n}, \mathrm{F}){ }^{99 m}$ Mo reaction in nuclear reactors by thermal neutron fluxes;

- ${ }^{98} \mathrm{Mo}(\mathrm{n}, \gamma){ }^{99} \mathrm{Mo}$ neutron capture reactions, where it is required to use the expensive enriched isotope ${ }^{98} \mathrm{Mo}$ for increasing the yield of ${ }^{99} \mathrm{Mo}$;

- direct production of ${ }^{99 m} \mathrm{Tc}$ in the reaction ${ }^{100} \mathrm{Mo}(\rho, 2 \mathrm{n}){ }^{99 m} \mathrm{Tc}$ using enriched ${ }^{100} \mathrm{Mo}$ (enrichment degree - up to $99 \%$;

- ${ }^{100} \mathrm{Mo}(\mathrm{n}, \gamma){ }^{99}$ Mo reactions, where intense photon fluxes, generated as a result of deceleration of an accelerated electron beam by heavy metals, dislodge photoneutrons out of ${ }^{100}$ Mo target;

- reactions of fission of the uranium isotope ${ }^{238} \mathrm{U}$ by photons ${ }^{238} \mathrm{U}(\gamma, \mathrm{F}){ }^{99} \mathrm{Mo}$.

As you can see, to obtain a medical isotope ${ }^{99 m} \mathrm{Tc}$ you can use slow neutrons of nuclear reactors or electron accelerators for high energies, which significantly complicates the process itself and increases the cost of the desired product.

One of the ways for mother isotope production is using the well-proven methods of generation enriched isotopes ${ }^{98} \mathrm{Mo}$ or ${ }^{100} \mathrm{Mo}$, however, the cost of these isotopes is quite high.

Therefore, search for inexpensive methods of

*Corresponding author E-mail address: tkachenko@kipt.kharkov.ua 
${ }^{98} \mathrm{Mo}$ or ${ }^{100} \mathrm{Mo}$ isotopes separation is today an urgent task.

Producing molybdenum by supercritical fluid extraction with carbon dioxide $\left(\mathrm{SFE}-\mathrm{CO}_{2}\right)$ was studied experimentally and theoretically in a number of studies $[5,6]$. In these studies molybdenum was extracted with tributyl phosphate solutions from nitric acid solutions [5]. The molybdenum extraction was of low efficiency due to its low solubility in dilute nitric acid, as well as due to its occurrence in nitric acid solutions in the form of various compounds $[5,6]$.

In this regard, to increase the efficiency of molybdenum extraction it is required to search for new modifiers during extraction.

This paper presents the results of experimental studies of the supercritical fluid extraction with carbon dioxide of non-nitric acid complexes of molybdenum and its isotopes at a vertical temperature gradient.

\section{MATERIALS}

For SFE- $\mathrm{CO}_{2}$ extraction an acetylacetone-based molybdenum solution was prepared. Molybdic acid (AR) was used as the source of molybdenum. The initial solution was obtained in Soxhlet apparatus using $100 \mathrm{ml}$ of acetylacetone (CP) and $10 \mathrm{~g}$ of molybdic acid powder placed in a filter paper bag. After 20 cycles of Soxhlet apparatus operation, the upper vessel was completely filled with distilled acetylacetone and the remaining extract was extracted for further experiments. The concentration of the obtained molybdenum solution was about $25 \mathrm{mg} / \mathrm{ml}$.

\section{EXTRACTION OF MOLYBDENUM BY SFE-CO METHOD $_{2}$}

SFE- $\mathrm{CO}_{2}$ extraction was carried out on SFE-U unit using reactors with volumes of 50 and $100 \mathrm{ml}$. The initial extract in quantity of $100 \ldots 300 \mathrm{mg}$ was applied on filter paper and placed in the reactor. After reaching a pressure within the range of $15 \ldots 20 \mathrm{MPa}$ at a temperature of $40^{\circ} \mathrm{C}$, the sample was kept under these conditions within 20 to 60 minutes. Supercritical fluid was discharged through a restrictor into a conical chamber (CC) with a volume of $1.5 \mathrm{~cm}^{3}$ covered with the filter paper. Since molybdenum complex in the supercritical fluid is in a dissolved state at a pressure of more than $15 \mathrm{MPa}$, it is required to add carbon dioxide to the reactor during eluent discharge to maintain the pressure above $15 \mathrm{MPa}$, while preventing the molybdenum complex from deposition on the walls of the reactor.

As the pressure decreased, carbon dioxide together with the extracted material froze as a result of supercooling and filled the volume of CC. After filling the $\mathrm{CC}$ volume with a solid eluent the conical chamber was freed from it and the discharge of a new batch of eluent continued in a similar mode. The resulting solid eluent was placed in a glass, where $\mathrm{CO}_{2}$ was evaporated releasing the extract.

\section{DETERMINATION OF THE EXTRACTION EFFICIENCY}

To determine the efficiency of extraction, as well as the effect of pressure, exposure time and additives on it we used the method of weighing and the method of measuring the concentration of molybdenum using an X-ray fluorescence analyzer. Loss of mass of the extract applied to the filter paper was determined with an accuracy of $0.1 \mathrm{mg}$ using scales AN-50. The concentration of molybdenum was determined before and after the extraction using the X-ray analyzer KRAB3UM. Transition from $\mathrm{x}$-ray data to concentration was carried out with help of a calibration curve obtained using a solution of molybdic acid in hydrochloric acid.

$5 \mathrm{ml}$ of the initial solution contained $1 \mathrm{mmol}$ of molybdenum was used for calibration. By diluting the initial solution, four reference concentrations were obtained with a content of $4 / 5,3 / 5,2 / 5$, and $1 / 5$ of the initial one. To increase the reliability of measurements, the solution with a concentration of $1 / 5$ of the initial one was diluted in half.

Samples for measurement were obtained by applying $0.05 \mathrm{ml}$ of these solutions on filter paper, followed by drying. The resulting calibration dependence is shown in Fig.1, where experimentally measured points are marked with markers.

Calibration line $y=a+b x$ in Fig. 1 was obtained by the least squares method in the MATCAD, where $a=627.823, b=300.059$. The values of the statistical coefficients are presented in Table 1.

Table 1. The values of the statistical coefficients at plotting the calibration line $y=a+b x$

\begin{tabular}{|l|l|}
\hline Correlation coeff., corr $(x, y)$ & 0.9861 \\
\hline$R_{2}, \operatorname{corr}(x, y)^{2}$ & 0.972 \\
\hline Covariance, cvar $(x, y)$ & 27.694 \\
\hline Standard Error, stderr $(x, y)$ & 18.824 \\
\hline
\end{tabular}

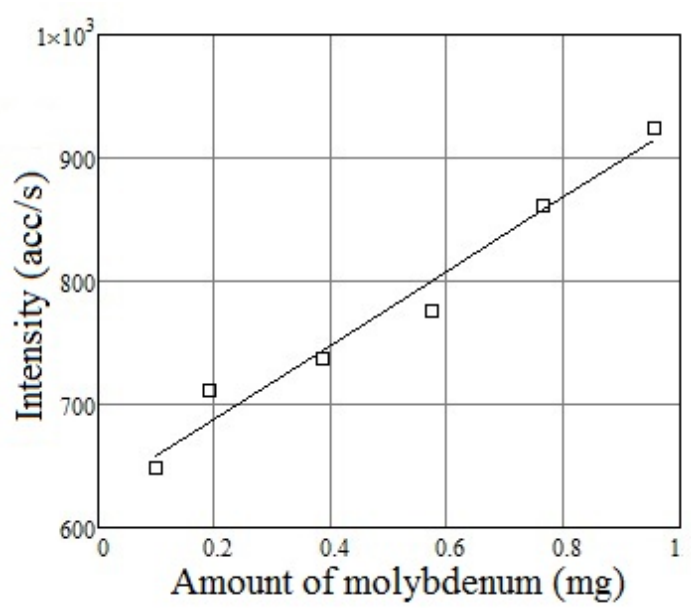

Fig.1. Calibration line of dependence of the number of readings of the X-ray analyzer KRAB-3UM on the content of molybdenum in reference solutions

The relative deviation of the experimental points from the calibration line $\triangle y(\%)$ is within the range of $-3.5 \leq \triangle y \leq 3.1$. 
The relative calibration error is determined by Standard Error and is of the order of $2.3 \%$.

Analysis of the results of $\mathrm{SFE}-\mathrm{CO}_{2}$ extraction of molybdenum has indicated that the efficiency of molybdenum separation decreases sharply, when the pressure of the extract decreases below $20 \mathrm{MPa}$.

Besides, the effect of extract exposure time on the efficiency of SFE- $\mathrm{CO}_{2}$ extraction was investigated.

The results of study the dependence of the efficiency of SFE- $\mathrm{CO}_{2}$ extraction of molybdenum on the extract exposure time are presented in Fig.2.

Line of the dependence of the quantity of the extracted molybdenum on the extract exposure time $y=a_{1}+b_{1} x$ in Fig. 2 was obtained by the least squares method in the MATCAD, where, $a_{1}=0.359$, $b_{1}=6.428 \cdot 10^{3}$. The values of statistical coefficients are presented in Table 2 .

Table 2. The values of the statistical coefficients at plotting the calibration line $y=a_{1}+b_{1} x$

\begin{tabular}{|l|l|}
\hline Correlation coeff., $\operatorname{corr}(x, y)$ & 0.8928 \\
\hline$R_{2}, \operatorname{corr}(x, y)^{2}$ & 0.797 \\
\hline Covariance, cvar $(x, y)$ & 2.408 \\
\hline Standard Error, $\operatorname{stderr}(x, y)$ & 0.072 \\
\hline
\end{tabular}

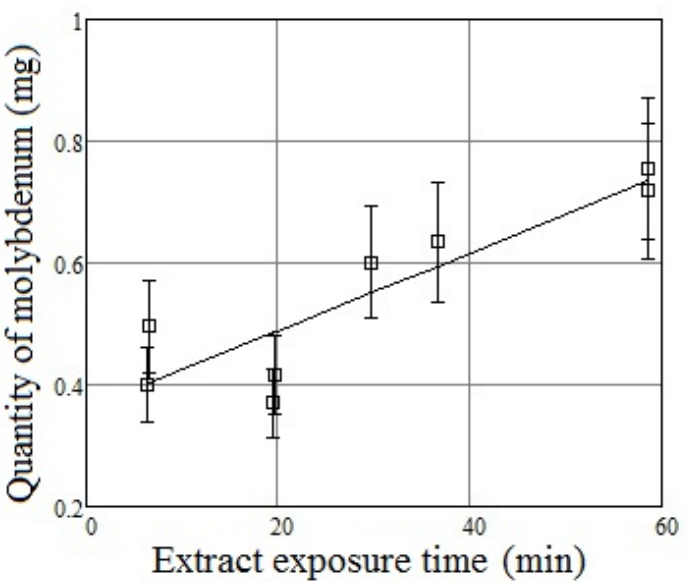

Fig.2. The quantity of the extracted molybdenum versus the exposure time of the extract

The relative deviation of the experimental points from the line of the dependence of the quantity of the extracted molybdenum on the extract exposure time $\triangle y(\%)$ range within $-18.9 \leq \triangle y \leq 16.5$.

The relative error in determining the quantity of extracted molybdenum is determined by Standard Error, it includes the calibration error and is of the order of $2.3 \%+0.072 / 0.55 \cdot 100 \%=15.4 \%$.

Analysis of Fig.2 shows, that at a pressure of $20 \mathrm{MPa}$ the quantity of the extracted molybdenum increases linearly with increasing the extraction time.

\section{REACTOR OF THE EXPERIMENTAL UNIT FOR ISOTOPE SEPARATION}

Experiments on study of SFE- $\mathrm{CO}_{2}$ complexes of molybdenum isotopes were carried out on a laboratory SFE-U supercritical fluid extraction unit, which had been previously used for separation of uranium isotopes [7].

The pressure of supercritical carbon dioxide in the unit could raise up to $20.0 \mathrm{MPa}$ and the temperature of the bottom and upper flanges of the reactor was maintained at a given level in the range $(20 \ldots 50)^{\circ} \mathrm{C}$ using adjustable heaters. In the experiments the temperature of the bottom flange was set above the temperature of the upper one. The layout of the reactor elements is shown in Fig.3.

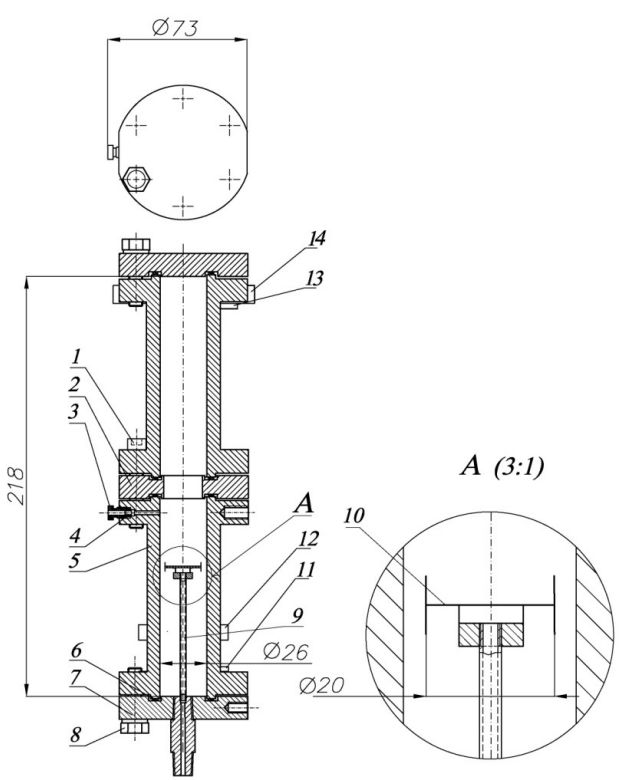

Fig.3. The layout of the reactor elements: 1. Bolt; 2. Middle flange; 3. Fitting; 4. Sealer; 5. Housing; 6. Filler; 7. Bottom flange; 8. Bolt; 9. Tube; 10. Intake; 11. Temperature sensor of the bottom flange; 12. Heating element of the bottom flange; 13. Temperature sensor of the upper flange; 14. Heating element of the upper flange

The tube 9 concentrically located in the housing 5 in Fig. 3 is made of stainless steel with a diameter of $6.1 \mathrm{~mm}$ and a wall thickness of $1 \mathrm{~mm}$. At the end of the tube there is an intake device 10 (see A in large scale in Fig.3.) in the form of an umbrella, which allows to dose the part of the extract from the reactor by reducing the pressure in it. The pressure is reduced to about 4.0 MPa. During the discharge of eluent carbon dioxide was added to the reactor in order to maintain a pressure above $15 \mathrm{MPa}$ and to prevent the complex deposition on the walls of the reactor. The intake in each set of experiments was located at a given distance from the bottom flange of the reactor.

\section{PROCEDURE FOR CARRYING OUT EXTRACTION}

On the SFE-U unit with a reactor, the layout of which is shown in Fig.3, the extraction was carried out according to the procedure as follows: 
- filter paper with the initial extract applied on it in quantity of 100 to $300 \mathrm{mg}$ was placed in the reactor;

- the upper flange of the reactor was heated to $\mathrm{T}_{1}=35^{\circ} \mathrm{C}$, the bottom flange - to $\mathrm{T}_{2}=45^{\circ} \mathrm{C}$;

- the pressure of carbon dioxide in the reactor was set at $20.0 \mathrm{MPa}$;

- the extract exposition in the reactor constitutes 0,$5 ; 1 ; 2$ hours;

- the extract was discharged in CC of volume $1.5 \mathrm{~cm}^{3}$.

The separation of the extract was carried out through the intake device 10 , the inlet of which was located at a distance of 150 and $50 \mathrm{~mm}$ from the bottom flange of the reactor.

\section{DETERMINATION OF EXTRACTION EFFICIENCY}

The initial sample of the solution (before the SFE$\mathrm{CO}_{2}$ extraction) and the samples obtained as a result of the SFE- $\mathrm{CO}_{2}$ extraction were analyzed for the content of molybdenum isotopes using the spectra obtained on a high-resolution mass-spectrometer with ionization in inductively coupled plasma ICPMS ELEMENT 2 [8].

The data on the natural content of Mo isotopes are presented in Table 3: column 2 - reference data; column 3 - data obtained on the high-resolution mass-spectrometer.

As you can see, the comparison of two columns of this Table indicates the full compliance of the reference data and data obtained during the extraction on the mass-spectrometer.

Table 3. The comparative content of molybdenum isotopes in the sample and in the initial solution

\begin{tabular}{|l|l|l|}
\hline Mo & Natural content, $\%$ & $\begin{array}{l}\text { The content in the } \\
\text { initial solution, } \%\end{array}$ \\
\hline 92 & 14.84 & $14.8063 \pm 0.1429$ \\
\hline 94 & 9.25 & $9.31356 \pm 0.19903$ \\
\hline 95 & 15.92 & $15.90653 \pm 0.19113$ \\
\hline 96 & 16.86 & $16.62644 \pm 0.19945$ \\
\hline 97 & 9.55 & $9.64547 \pm 0.17835$ \\
\hline 98 & 24.13 & $24.01053 \pm 0.44074$ \\
\hline 100 & 9.63 & $9.69117 \pm 0.0978$ \\
\hline
\end{tabular}

The data on the content of Mo isotopes in the eluent depending on the level of the eluent sampling and the extraction time are presented in Table 4.

The data in Table 4 will be analyzed graphically. The results of the analysis of the Mo isotopes content in the eluent depending on the level of eluent sampling and the time of extraction are presented in Fig.4.
Table 4. The content of Mo isotopes in the eluent depending on the eluent sampling point and the extraction time

\begin{tabular}{|l|l|l|}
\hline Mo & \multicolumn{1}{|c|}{ a) } & \multicolumn{1}{c|}{ b) } \\
& & \\
\hline 92 & $15.0315 \pm 0.11479$ & $14.78538 \pm 0.28476$ \\
\hline 94 & $9.63151 \pm 0.13789$ & $9.28773 \pm 0.09753$ \\
\hline 95 & $15.66674 \pm 0.28077$ & $116.01984 \pm 0.10342$ \\
\hline 96 & $16.52582 \pm 0.11608$ & $16.60246 \pm 0.23393$ \\
\hline 97 & $9.61914 \pm 0.123$ & $9.41784 \pm 0.12812$ \\
\hline 98 & $23.91133 \pm 0.24912$ & $24.30584 \pm 0.37178$ \\
\hline 100 & $9.61396 \pm 0.09693$ & $9.58088 \pm 0.05751$ \\
\hline
\end{tabular}

\begin{tabular}{|l|l|l|}
\hline Mo & \multicolumn{1}{|c|}{ c) } & \multicolumn{1}{c|}{$\mathrm{d})$} \\
& & \\
\hline 92 & $14.8421 \pm 0.16045$ & $15.33418 \pm 0.29948$ \\
\hline 94 & $9.23206 \pm 0.15126$ & $10.04887 \pm 0.18899$ \\
\hline 95 & $15.90277 \pm 0.24931$ & $15.54153 \pm 0.29700$ \\
\hline 96 & $16.50179 \pm 0.24224$ & $16.53139 \pm 0.32962$ \\
\hline 97 & $9.52157 \pm 0.19548$ & $9.35543 \pm 0.14426$ \\
\hline 98 & $24.48921 \pm 0.37556$ & $23.81031 \pm 0.52268$ \\
\hline 100 & $9.51049 \pm 0.19916$ & $9.37829 \pm 0.18021$ \\
\hline
\end{tabular}

In Fig.4 the confidence interval for measuring the isotope content is given by horizontal segments, which are located on a vertical segment passed through the corresponding mass value of the Mo isotope. Tabular values of the natural content of Mo isotopes in Fig. 4 are shown with a cross. It follows from a comparison of Figs.4, a, c, that during the extract exposition for 1 hour at a temperature gradient in the reactor of $\gamma_{15}=\left(T_{2}-T_{1}\right) / L=10 / 15=$ $0,667^{\circ} \mathrm{C} / \mathrm{m}$, Mo isotopes with masses $(92,94)$ are enriched and the isotope with a mass 96 is depleted in comparison with their natural content.

At a large temperature gradient of $\gamma_{5}=10 / 5=$ $2{ }^{\circ} \mathrm{C} / \mathrm{m}$ and at the same extract exposure time there is no change in the eluent isotopic composition compared to natural one.

In the case of a large temperature gradient in the reactor $\gamma_{5}$, changing the isotopic composition of Mo over time is a fairly long process. It is noticeable when the extract exposition lasts for 2 hours. In this case, there is a stronger effect of changing the isotopic composition, compared with a small temperature gradient. For example, in Fig.4, d, isotopes with masses $(92,94)$ are more enriched than in the case of Fig.4, a, and heavier isotopes $(95,97,100)$, in contrast to the small temperature gradient, where there is no enrichment, become depleted in comparison with the natural composition. 


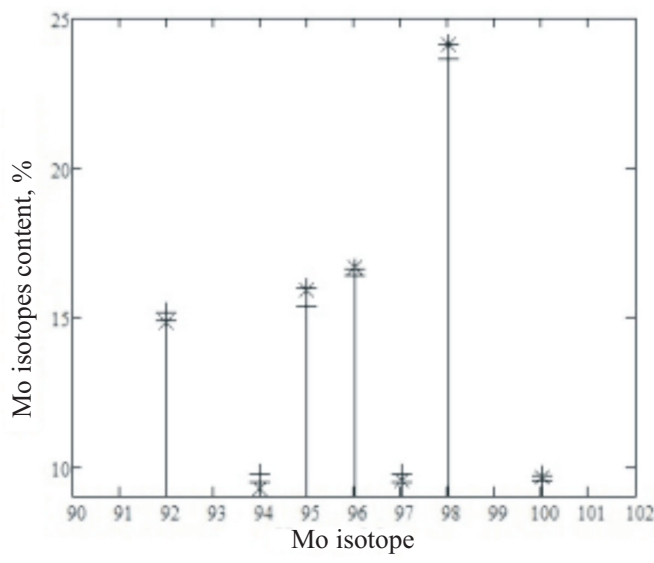

a

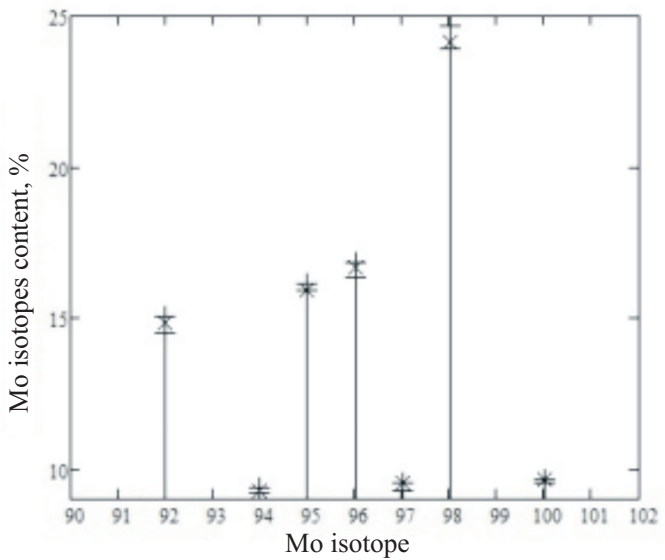

b

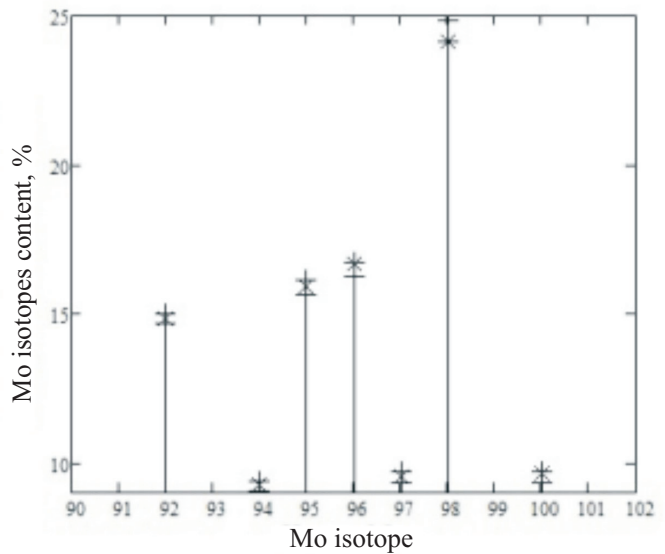

C

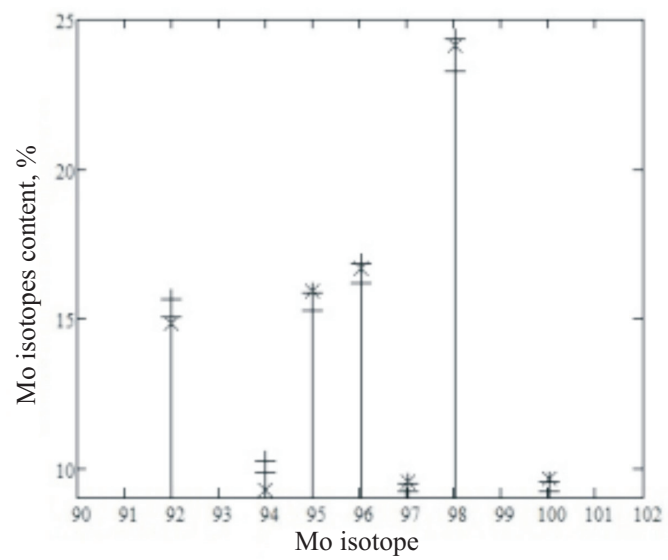

d

Fig.4. Mo isotopes content in the eluent versus the level of eluent sampling and the extraction time

\section{CONCLUSIONS}

Separation of molybdenum complexes and its isotopes by the SFE- $\mathrm{CO}_{2}$ method was studied in this paper. The type of modifier, the fluid exposure time and the pressure in the reactor were determined at which the most efficient separation of the metal and its isotopes was guarantied. A set of experiments on the extraction of molybdenum isotope complexes was carried out in the upgraded SFE-U unit at a constant pressure $\mathrm{P}=20 \mathrm{MPa}$ and constant temperatures of the bottom $\left(\mathrm{T}_{2}=45^{\circ} \mathrm{C}\right)$ and upper $\left.\mathrm{T}_{1}=35^{\circ} \mathrm{C}\right)$ flanges of the extraction chamber. In each of the experiments the exposure time of the extract and the level of the height of the eluent sampling from the extraction chamber were varied.

Based on the performed experiments we can draw the following conclusions:

1. Deviation of the Mo isotopes content from the natural one in the eluent is observed at a low temperature gradient and at the extract exposure for 1 hour: isotopes 92,94 are poorly enriched and isotope 96 is depleted.

2. At a large temperature gradient, when the fluid exposition constitutes 1 hour, no change in the isotopic composition of the eluent is observed.

3. At a large temperature gradient the isotopes with small masses $(92,94)$ have greater enrichment compared to the case of a small temperature gradient. At that, heavier isotopes $(95,97$, and 100) in contrast to the case of a small temperature gradient, where only isotope 96 is depleted, become depleted in comparison with the natural composition.

4. Apparently, no changes in the isotopic composition in case b) is explained by insufficient exposure time of the fluid.

In conclusion, the authors express gratitude to Kazarinov Yu.G. for participating in the experiments and their processing.

The work was carried out for the account of the budget program "Support for the development of priority research areas".

\section{References}

1. V.K. Karandashev, A.N. Turanov, S.V. Nosenko. Analiz oksyda molibdena metodami atomnoy emisiii ta mas - spektrometriii $\mathrm{s}$ induktyvno zv'yazannoy plazmoy // Zhurnal analiticheskoy khimii. 2011, v.66, N.1, p.40-46 (In Russian).

2. https://

www.sisweb.com/referenc/source/exactmas.htm

3. I.N. Bekman. Radiokhimiya, v.2t. T.1. Fundamental'naya radiokhimiya: uchebnik i praktikum dlya akademicheskogo bakalavriata. M.: Izdatel'stvo Yurayt. 2015, 473 p. (In Russian).

4. I.S.Guk, S.G. Kononenko, F.A. Peyev. O vozmozhnosti proizvodstva diagnosticheskogo med- 
itsinskogo izotopa tekhnetsiya 99M v Ukraine // Vestnik Khar'kovskogo universiteta, seriya fizicheskaya: "Yadra, chastichki, polya". 2010, N.916, Iss.3/47/, p.117-126 (In Russian).

5. N.D. Goletskiy,

L.G. Mashirov, B.YA.Zil'berman. Ekstraktsiya molibdena rastvorami tributilfosfata iz peresyshchennykh azotnokislykh rastvorov // Radiokhimiya. 2010, v.52, N.2, p.155-161 (In Russian).

6. B. Borts, A. Palamarchuk, V. Tkachenko, S. Skoromnaya. The study of supercritical extraction of complexes of molybdenum with carbon dioxide // Eastern-European journal of enterprise technologies. 2016, N.6/6 (84), p.57-63

(In Russian).

7. B.V. Borts, YU.G. Kazarinov, I.M. Neklyudov, S.F. Ivanova, V. I. Tkachenko. Prostranstvenno neodnorodnoye raspredeleniye izotopa uran-235 pri sverkhkriticheskoy flyuidnoy ekstraktsii dioksidom ugleroda $\mathrm{v}$ gradiyentnom pole temperatur // PAST. Ser. Materialovedeniye i novyye materialy. 2015, N.4(83), p.81-91 (In Russian).

8. V.N. Muzgin,

H.H. Yemel'yanova, A.A.Pupyshev. Mass-spektrometriya s induktivno-svyazannoy plazmoy - novyy metod $\mathrm{v}$ analiticheskoy khimii // Analitika i kontrol'. 1998, N.3, p.3; N.4, p.25 (In Russian).

\title{
СВЕРХКРИТИЧЕСКАЯ ФЛЮИДНАЯ ЭКСТРАКЦИЯ ДИОКСИДОМ УГЛЕРОДА КОМПЛЕКСОВ МОЛИБДЕНА И ЕГО ИЗОТОПОВ
}

\author{
Б. В. Бори, Л. А. Булавин, С. Ф. Скоромная, В. И. Ткаченко
}

Экспериментально исследовано выделение комплексов молибдена и его изотопов методом сверхкритической флюидной экстракции диоксидом углерода. Определен вид модификатора, который обеспечивает повышение эффективности выделения металла и его изотопов. Экстракция комплексов изотопов молибдена проводилась в модернизированной установке СФЭ-U при постоянном значении начального давления $\mathrm{P}=20 \mathrm{MПа} \mathrm{и} \mathrm{постоянных} \mathrm{значениях} \mathrm{температур} \mathrm{верхнего} \mathrm{T}_{1}=35{ }^{\circ} \mathrm{C}$ и нижнего $\mathrm{T}_{2}=45{ }^{\circ} \mathrm{C}$ фланцев экстракционной камеры. В экспериментах задавались время выдержки экстракта и уровень по высоте экстракционной камеры, откуда проводился отбор элюента. Показано, что на определенной высоте отбора пробы и при определенных временах выдержки в экстрактах наблюдается изменение природного содержания изотопов Мо.

\section{НАДКРИТИЧНА ФЛЮЇДНА ЕКСТРАКЦІЯ ДІОКСИДОМ ВУГЛЕЦЮ КОМПЛЕКСІВ МОЛІБДЕНУ І ЙОГО ІЗОТОПІВ}

\section{Б. В. Бори, Л. А.Булавін, С. Ф. Скоромна, В. І. Ткаченко}

Експериментально досліджено виділення комплексів молібдену і його ізотопів методом надкритичної флюїдної екстракції діоксидом вуглецю. Визначено вид модифікатора, який забезпечує підвищення ефективності виділення металу і його ізотопів. Екстракція комплексів ізотопів молібдену проводилася в модернізованій установці СФЕ-U при постійному значенні початкового тиску P = 20 МПа і постійних значеннях температур верхнього $\mathrm{T}_{1}=35{ }^{\circ} \mathrm{C}$ і нижнього $\mathrm{T}_{2}=45^{\circ} \mathrm{C}$ фланців екстракційної камери. В експериментах задавалися час витримки екстракту і рівень по висоті екстракційної камери, звідки проводився відбір елюєнта. Показано, що на певній висоті відбору проби і при певних часах витримки в екстрактах спостерігається зміна природного вмісту ізотопів Мо. 